\title{
A Study on Consumer Behavior of Commercial Health and Fitness Club-A Case of Consumers in Liverpool
}

\author{
Wen Zhang, Yuhong Li* \\ Business School, Jinggangshang University, Ji’an, China. \\ Email: "liyuhong0718@hotmail.com
}

Received December $23^{\text {rd }}$, 2013; revised January $10^{\text {th }}$, 2014; accepted January $17^{\text {th }}$, 2014

Copyright (c) 2014 Wen Zhang, Yuhong Li. This is an open access article distributed under the Creative Commons Attribution License, which permits unrestricted use, distribution, and reproduction in any medium, provided the original work is properly cited. In accordance of the Creative Commons Attribution License all Copyrights @ 2014 are reserved for SCIRP and the owner of the intellectual property Wen Zhang, Yuhong Li. All Copyright (C) 2014 are guarded by law and by SCIRP as a guardian.

\section{ABSTRACT}

Commercial health \& fitness clubs are providing an important kind of sporting service. On the basis of questionnaires and interviews with relevant research results, consumers of health \& fitness clubs in Liverpool area are studied about their structures including ages, genders, etc., motivation of consumption, and consumption level as well as demand characteristics. Through impressing on the wheel of consumer behavior model, the factors affecting consumer behavior are also analyzed. The most predictable and accessible segments like young adult, affluent, health or appearance conscious consumers are concluded; their lifestyles easily integrate to leisure activities, and time pressure or financial costs are their key concerns. Targeting marketing strategies of the clubs are suggested accordingly in order to design service channel, price reasonably, communicate with consumers and provide satisfying environment.

\section{KEYWORDS}

\section{Health \& Fitness; Consumer Behavior; Liverpool; Marketing}

\section{Introduction}

Health \& fitness clubs not only have an important position in social sporting service, but also reflect the importance of health care. Health \& Fitness clubs include profit organizations and non-profit organizations. For profit organizations, health \& fitness club can also be called commercial health \& fitness club. As Liverpool region is the birthplace of football, local people's enthusiasm for sports has a long history. With the continuous improvement of living standard, there are many chronic diseases which appear in middle age and even younger age. Liverpool area residents are studied because their life qualities have also been affected by obesity, hypertension, fatty liver and other diseases.

Commercial health \& fitness club has a role in promoting the local economy. Also, it produces good social benefits in strengthening the spiritual and cultural construction and improving residents' well-being index. In order to further promote the sustainable development of *Corresponding author. commercial health \& fitness club, it is necessary to investigate and analyze its service orientation, characteristics and structure of consumer demand, spending power and influential factors, and on this basis, to explore targeted marketing strategies. This paper aims to study the consumer structure of health \& fitness clubs in Liverpool area, their motivation, consumption, consumer demand, and targeted marketing strategies based on previous studies, and it has a very important practical significance for health \& fitness club managers, investors and the Government as a reference.

\section{Research Methodology}

This report provides a comprehensive investigation of the UK health \& fitness sector through primary and secondary market research. The research method involved a comprehensive secondary research study of UK health and fitness market reports together with an investigation of academic articles relating to the sector and general consumer behaviors. Salient points were categorized and 
priorities identified to be tested through primary research. A questionnaire was developed to test the points for a local representative sample of consumers (see appendixes). The results were then compared and analyzed. The primary research used a quantitative based approach sampling local consumers.

Solomon et al. [1] proposes a "wheel of consumer behavior" to help explain the complex interrelationships between individual consumers and their social realities (see Figure 1). In the context of a health and fitness consumer this provides a useful framework for understanding the forces and processes that are impacting upon consumers and affect their behaviors.

\section{Literature Review}

\subsection{Consumer Structure}

Swimming is a factor for families, but those with children are less likely to exercise frequently. Family dynamics are important in determining usage behavior, but finances have critical impacts on decision making [2]. Gender can also relate to how service empathy is provided. Research shows that females are more predisposed with a preference to talk about reasons for exercising and their goals with other females [3]. Similarly, existing lifestyle matches have stronger impacts on consumers, when participants' lifestyles are similar to those targeted [4].

\subsection{Motivation}

Significant numbers of consumers never exercise and appear to have no interest in joining a health club. Lack of interest appears to be the reason for a third of consumers, while cost of use of public facilities is an inhibitor for $13 \%$ of consumers [5]. Ownership of fitness equipment is increasingly popular as home workout provides greater time and frequency flexibility, but faces competition from other home entertainment trends [6]. Exercise is considered leisure behavior, but offers a prospect of an external reward [7]. The research sets out principal incentives as relaxation, stress relief; social/ self-improvement, appearance/self-esteem and competence challenge [8]. There is a trend towards health and this may be reflected in the increasing popularity of outdoor fitness [5]. Health conscious consumers (or wellness-oriented) are more interested in more holistic life

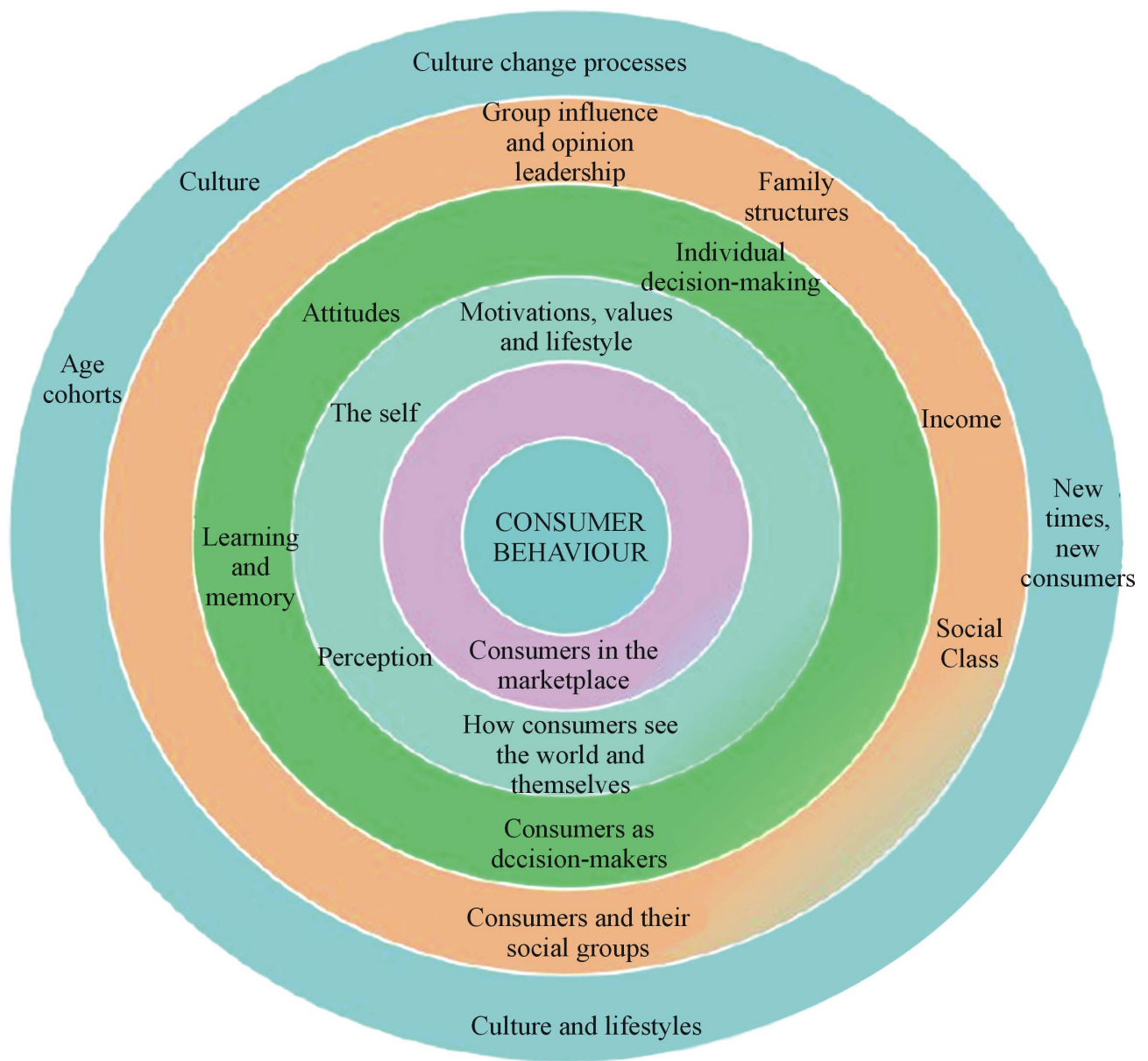

Figure 1. Solomon's Wheel of Consumer Behavior (Solomon, Bamossy, Askegaard, \& Hogg, 2010) [1]. 
styles, concerned with "nutrition, fitness, stress and their environment” [9].

\subsection{Consumption}

Family recreation needs and higher standards of living created growth in private fitness and health clubs, though trends towards busier consumer lifestyles and the economic downturn now mean that consumers seem less able to commit to regular fitness, sports and competitions [2]. Respondents state that they do not have time to exercise, find it un-enjoyable, and become intimidated and/or anxious [10]. As health and fitness is leisure time based, lifestyle is an important factor. Whilst many indicate sport is important to them, lack of time/energy or financial reasons inhibits consumption [2]. Negative attitudes seem more prevalent than positive ones towards exercise.

\subsection{Demand Characteristics}

Swimming, cycling, aerobics and fitness classes are popular fitness activities [2], although [11] highlight walking and jogging as prevalent, high frequency and trending. Fitness classes help introduce a social element to classes and activities such as aerobics, circuit training, yoga, martial arts and dance attract between $6 \%$ and $11 \%$ of consumers [12]. Regular users of health and fitness clubs use more involved decision making as they perceive more risk [13]. Consumers exercise in a group or on their own, but social bonding need is highly unpredictable in individuals [7]. Singular consumers' expectations towards the levels of service offered by staff depend upon their self-responsibility levels [3].

\subsection{Influential Factors}

Self-concepts influence the level of concern towards own weight, fitness levels as well as anxiety associated with encountering other members, staff and equipment [3]. Psychological involvement in health and fitness influences levels of activity importance to the individual, their level of interest and frequency of cognition [8]. Deeprooted psychological preoccupations with gender or body consciousness/former health, mental or emotional problems influence consumer's interest and motivation and how health club empathy is assessed [3], in fact, psychological variables like perceived health status may be better predictors of health behaviors than demographics [14]. The image of a fit body is increasingly a mark of social standing and for some segments the drive is to look good rather than feel healthy [15]. Needs may depend upon racial, cultural and religious factors. For example, true empathy with the needs of ethnic sub-groups can add greatly to service value for those consumers, conversely for experienced users, the artifacts and equipment are paramount [3].

\subsection{Targeted Marketing Strategies}

Private Health Clubs tend to use structural and financial methods to retain customers, but this is easily imitated and does not work to establish real social bonding between them. Creating loyalty by attitudinal and social relationships and to engender positive word of mouth may be more successful [13]. Loyalty appears to relate to lifecycle as younger members of health clubs (18 to 24) are more willing to switch clubs, whereas, families with children and "third agers" (55+) seem more loyal [16]. Consumers tend to exercise for longer periods at the weekends as opposed to only half hour midweek and a lack of convenience can inhibit [12]. Large private gyms are more urban with "original suburb" and "city adventurers" prominent [2].

\section{Research Results}

The results of the primary research undertaken are compared with secondary research to test the main premises, using Solomon's "wheel of consumer behavior" as the structural framework (see Figure 1).

\subsection{Consumers in the Marketplace}

Consumers are finding ways of exercising for less financial expenditure $[5,6]$. From the primary research, financial reasons for not joining were $26.67 \%$ with free outdoor activities preferred by $17.33 \%$ of the sample. This demonstrated that financial reasons are an important inhibitor and some consumers will select the available alternatives.

Consumers use affordability, convenience, cleanliness, club status and clientele as core factors [2,5]. The primary research partly reinforced this with the most important factor as price (30.77\%), second convenience (27.47\%) and third facilities (20.88\%). Brand status was not important within the sample.

The importance of "service-support needs" varies depending upon the self-reliance, knowledge/expertise levels [3]. Primary research showed that service support need was not a strong factor at $10.99 \%$ but that consumers sampled had mixed responses to competitors service level, Services appear important for reducing anxiety as (24.14\%) of the sample thought personal-trainers may reduce equipment concerns.

Significant numbers of consumers never use health and fitness clubs [2,5]. This was supported by primary research as results indicated $35.16 \%$ of the sample never exercised. This was similar to the Keynote survey results of $35 \%$. 


\subsection{How Consumers See the World and Themselves}

Exercise is used to improve body-image and self-esteem, to improve health, fitness and strength and to achieve proficiency challenges [8]. In the primary research, 30.82\% stated that improving health was their main motivation, followed by "to lose weight" (23.29\%), "look good" (14.38\%) and "relax" (11.64\%). Perceptions regarding own body-image/fitness-levels in relation to individual's ideals creates motivation $[6,8,15,17]$. The primary research showed that concerns were stronger for health in the sample.

Body image is an important component of status/selfesteem and has a social "currency" $[15,6]$. The primary research did not strongly validate this hypothesis as health goals were more prevalent than "looking good". Consumers are more likely to be anxious regarding their health and fitness levels at specific stages of their lifecycle [15]. The primary research indicated that gym membership was most attractive to 16 to 35 year olds.

Deeply ingrained gender/body awareness affects anxiety levels regarding use of health clubs [3,15]. Gender separation and more privacy were cited as helpful for reducing anxiety for some consumers in the primary research.

Males are increasingly subjected to objectification of the body, although bulk and not tone is the desired outcome [15]. The primary research did not strongly validate this as health goals and reducing weight were stronger results although there was preference amongst males to improve self-esteem and socialize.

Consumers often have negative attitudes to fitness due to a lack of satisfaction, enjoyment or frustration with results [6]. The primary research indicated that time pressures $(32.00 \%)$ was the main inhibitor, $8 \%$ found exercise boring, while 5.33\% lacked energy.

Participants become psychologically attached to particular activities [7]. The primary research failed to support this with weak results for previous experience as factors in choices.

\subsection{Consumers as Decision Makers}

Financial structures to retain customers are reproducible, while empathizing with consumers needs attracts psychological loyalty $[18,19]$. The primary research indicated that subscription and pay as you go models were equally popular and that other factors such as price, facilities and convenience were more important factors than services.

Family cycle stages affect consumption since childcare commitments impact upon time-availability and family-recreation behaviors [2]. The results from the primary research were skewed by a lack of parents par- ticipating in the survey and family friendly preference (7.69\%) reflected this. Family members or friend opinions were weakly indicated as factors for health club choice (6.59\%). Credibility of sources appears an important component in health and fitness marketing [4]. This was not tested in the primary research.

\subsection{Consumers and Their Social Groups}

Health and fitness is used to relax and unwind, to meet new people and engage with friends [8,9]. The primary research showed strong preference for relaxing environments (62.64\%), although "to relax" as a primary motivation was weak (11.64\%). More females preferred relaxing environments, while males chose between high energy and relaxing environments.

Consumers are either inclined to exercise on their own or use social groups to aid motivation [2,7,8,12,15]. While this was not directly framed in the research, socialization was less important than secondary research findings suggested.

Intimidation is an issue, heightened with females and certain ethnic subgroups where dress modesty and/or exercising in front of males are factors $[6,20]$. The primary research supported this, with $34.48 \%$ of the sample stating that female only time and separate gender exercise would reduce their anxiety.

Females prefer to empathize with other females regarding health/fitness anxieties and goals [3]. This was not directly tested in the primary research, although other gender related anxieties and importance of personal trainers in reducing anxiety point a possible need to explore further.

\subsection{Culture and Lifestyles}

Health and fitness has a leisure/recreational component, but there is a need for a "prospect of external reward". [7]. The primary research found external rewards such as health/ appearance benefits as key.

Many consumers experience time pressures meaning health \& fitness can be difficult to integrate with their lifestyles $[1,2,6,10,11]$. The primary research supported this with $32 \%$ of respondents stating time pressure as the principal reason for not exercising.

Those that are successful form habits or rituals that integrate with their daily or weekly routines [10]. The primary research showed that convenience (27.47\%) is an important factor and participants had strong preferences for when they exercised; (47.25\%) evening and (38.46\%) weekend.

Music can play a role in developing consumer's enjoyment and loyalty, but needs vary with age. Although this was not directly tested in the primary research, $62.64 \%$ of participants stated a preference for a relaxing envi- 
ronment, while $29.67 \%$ preferred a high energy environment which provides insight to music choices and potential conflicts.

Higher earners appear to be the heaviest users of private health clubs [2]. This was not directly tested in the primary research. Lifestyles that negatively affect health may cause consumers to compensate by exercising in an attempt to ward off potential health problems [21]. The need to lose weight and acquire health benefits featured strongly in the primary research.

\section{Conclusion and Discussion}

This investigation finds that health and fitness consumers can be segmented by their health and fitness needs, drives, recognized rewards and their lifestyles. Age, family lifecycle and geo-demographic factors impact upon those elements and while more measurable are less predictable for determining health and fitness behaviors (see Figure 1). Consumer's individual personalities, group activities, socio-cultural and ethnic preferences influence choices and can provide challenges in meeting conflicting needs.

Young, affluent, health and appearance conscious consumers whose lifestyles are easily integrated to health and fitness clubs and have positive attitudes to exercise are the most predictable segments. However, consumer's needs and preferences change at key areas of their lifecycle and family stages and perhaps offer niche or more customized opportunities. Overt health drives appear to be stronger than appearance, although it is possible that they are linked and cryptic in nature.

There appears to be a divide between consumers who prefer relaxing environments and those who favor highenergy situations. Some consumers choose to exercise alone, while others desire socialization. Then, there was a stronger preference for relaxation.

Many consumers construct negative psychological connections towards health and fitness. It is therefore imperative that marketing strategies overcome these engendered attitudes.

Consumers are time and financially pressurized. The challenge is therefore for private health and fitness clubs to provide conditioning techniques so consumers become aware of; are attracted to; and feel rewarded for using health clubs therefore associating them as pleasurable places to spend valuable leisure time where desired rewards are gained.

Commercial health \& fitness clubs should pay attention to market research and forecast, and study consumer behavior as the basis for market segmentation and business decisions. It requires them make management concepts from experience management to scientific management, deal with government actions and commercial fitness club to implement preferential policies in levying various taxes and fees, and simplify management procedures in order to mobilize the enthusiasm of investors.

Limitations in the sample included an abnormally small number of older consumers, parents and car owners than planned. The primary research hasn't proved directly that high earners may be the heaviest users of private health and fitness clubs. Importance of personal trainers and credibility of gym resources haven't been tested. As well, social class and psychological factors impacting on consumers are lacked. In order to obtain more complete information and explore potential market, broader population quantitative studies are recommended contemplating the optimum service configurations for proposed locations alongside qualitative studies to grasp the "veiled" health/body image drives and anxieties that inhibit consumption. These are needed to support the development of a robust marketing mix.

\section{Suggestions}

1) Service channel strategy. Service channel, also known as service intermediate, or service distributor. Service channel marketing refers to differentiating marketing which means that service enterprises through intermediates can provide service to end-customers. With the development of networked economy, it's inevitable to carry out multi-faceted service channels. From the primary research, time pressure (32\%) was the main reason for not exercising. Electronic channels will better increase the crowd and scale of health and fitness club, so that more consumers are able to keep service trends and project information. The research results also show that $27.47 \%$ participants point out the importance of convenience. They always prefer to exercise in the evening (47.25\%) and at the weekend (38.46\%). Health \& fitness clubs not only should satisfy consumers with a more efficient and convenient service, but also promote more flexible opening hours and curriculum arrangement in order to attract more people.

2) Service pricing strategy. More and more people have paid attention to how to improve health. According to the results, $30.82 \%$ indicated that their main motivation to exercise is improving health. Exercise has become a part of everyday life. From the primary research, price (30.77\%) is the most important reason for not exercising. "Spend money on health" for investment in health has been accepted by more and more people who provide the conditions to open up the vast health \& fitness market. Even though subscription and pay as you go models were equally popular from research results, price is still an important factor for consumer purchase behaviors. Generally, health \& fitness club should establish a reasonable price control mechanism, according to the actual needs of different consumer groups, to clear consumers' psychological trends for the price and take practical pricing and 
price adjustment strategies in order to ensure the success of the club marketing campaigns.

3) Service communication strategy. In order to change consumers' attitudes and influence their consumer behaviors, health \& fitness club staff must have sufficient communication with consumers. The primary research states that gym membership was most attractive to 16 to 35 year olds. For them, marketers need to design product, price, place, promotion and other means, so that consumers agree the necessity and importance of fitness and identify club services. Service communication needs to care about face to face communication, i.e. to help to solve problems of targeted consumers face to face. While it should be paid attention that $24.14 \%$ thought gender separation and more privacy are helpful in reducing anxiety, especially for females. $34.48 \%$ of the sample stated that time and separate gender exercise would reduce female's anxiety. More privacy, personal trainers and separate gender rooms should be considered by health and fitness clubs.

4) Service environment strategy. Environment has a significant impact on consumer emotion, feeling and behavior. Service environment includes decoration, color, furnishing, music and so on. Health and fitness clubs offer places for consumers, so environment would change psychological feelings in the process of their activities. From the primary research, males preferred to high energy and relaxing environments, however, females chose more relaxing environment. In total, it has $62.64 \%$ of participants preferring relaxing environment and $29.67 \%$ would like more music choices. A good environment will leave a good first impression and cause consumer behavior. Health and fitness clubs need to create a clean and comfortable environment to fully demonstrate sports and fitness ambience. According to consumer demand, health and fitness clubs need to improve interior space layout, personnel crowding and bathroom cleanliness constantly. In addition, the quality and image of service environment will change consumers' attitude and evaluation after purchasing.

\section{Acknowledgements}

This paper is financially supported by the projects Foreign Trade and Economic Development: Empirical Study on Southwest Minority Region of China (ID: JRB11046).

\section{REFERENCES}

[1] M. R. Solomon, G. Bamossy, S. Askegaard and M. K. Hogg, "Consumer Behavior," 4th Edition, Pearson Education Limited, London, 2010.

[2] Keynote, “Health Clubs \& Leisure Centers,” Keynote Ltd, 2010.

[3] E. Marandi and J. Harris, "The Impact of Perceived Ser- vice Provider Empathy on Customer Loyalty: Some Observations from the Health and Fitness Sector," Managing Leisure, Vol. 15, No. 3, 2010, pp. 214-227. http://dx.doi.org/10.1080/13606719.2010.483832

[4] R. Arora, C. Stoner and A. Arora, "Using Framing and Credibility to Incorporate Exercise and Fitness in Individuals' Lifestyle," Journal of Consumer Marketing, Vol. 23, No. 4, 2006, pp. 199-207. http://dx.doi.org/10.1108/07363760610674329

[5] Mintel, "Leisure Centers and Swimming Pools," Mintel International Group, 2010.

[6] Mintel, "Exercise and Sport For the Time-pressed Consumer," Mintel International Group, 2009.

[7] S. P. Vlachopoulos, N. D. Theodorakis and G. T. Kyle, "Assessing Exercise Involvement among Participants in Health and Fitness Centers,” European Sport Management Quarterly, Vol. 8, No. 3, 2008, pp. 289-304. http://dx.doi.org/10.1080/16184740802224191

[8] J. Woolf, "Competitive Advantage in the Health and Fitness Industry: Developing Service Bundles,” Sport Management Review, Vol. 11, No. 1, 2008, pp. 51-57. http://dx.doi.org/10.1016/S1441-3523(08)70103-7

[9] F. B. Kraft and P. W. Goodell, "Identifying the Health Conscious Consumer," Journal of Health Care Marketing, 2010, pp. 18-25.

[10] Mintel, "Fitness in the Home-Taking Advantage of the Desire to Save Time and Money,” Mintel International Group, 2009.

[11] Mintel, "Health \& Fitness Clubs, 'Keeping Pace with the Needs of Cash Strapped Consumers,” Mintel International Group, 2009.

[12] Mintel, "Fitness Classes," Mintel International Group, 2007.

[13] T. T. Campbell, J. D. Nicholson and P. J. Kitchen, “The Importance of Social Bonding and Loyalty: An Empirical Investigation within U.K. Private Health Clubs,” Journal of Hospitality and Leisure Marketing, Vol. 14, No. 1, 2006, pp. 49-73.

http://dx.doi.org/10.1300/J150v14n01_04

[14] M. H. Wetzel, "A Test of the Health Promotional Model with Blue Collar Workers,” Nursing Research, 1989, pp. 99-104.

[15] S. L. Dworkin and F. L. Wachs, "Body Panic: Gender, Health and the selling of Fitness," New York University Press, 2009.

[16] J. Oliver, "Exploring the Role of Music on Young Health and Fitness Club Member Loyalty: An Empirical Study,” Young Consumers, Vol. 8, No. 1, 2007, pp. 65-72. http://dx.doi.org/10.1108/17473610710733802

[17] L. G. Shiffman and L. L. Kanuk, "Consumer Behavior," Prentice Hall, 1999.

[18] S. Della Vigna and U. Malmendier, "Paying Not to Go to the Gym," American Economic Review, Vol. 96, No. 3, 2006, pp.694-719. http://dx.doi.org/10.1257/aer.96.3.694

[19] S. D. Vigna and U. Malmendier, "Overestimating Self Control: Evidence from the Health Club Industry,” National Bureau of Economic Research, Berkeley, 2004. 
[20] Trinity Mirror, “South Liverpool Mersey Mart,” 2010. http://www.Trinitymirrornorthwest.co.uk/Merseyside/sou th-liverpool-merseymart/.

[21] M. T. French, I. Popovici and J. C. Maclean, "Do Alcohol
Consumers Exercise More? Findings from a National Survey," American Journal of Health Promotion, Vol. 24, No. 1, 2009, pp. 2-10.

http://dx.doi.org/10.4278/ajhp.0801104 


\section{Appendix A-Primary Research Design \& Questionnaire}

Questionnaire about Health Club and Fitness Centers

1. Home location: $\square$ city centre $\square$ Sefton $\square$ North Liverpool $\square$ South Liverpool $\square$ Knowsley $\square$ St. Helens $\square$ others

2. Age: $\square$ under $16 \square 16-25 \square 26-35 \square 36-45 \square 46$ - $55 \square 56$ - $65 \square$ above 66

3. Gender: $\square$ Male $\square$ Female

4. Do you have children under 14 ? $\square$ Yes $\square$ No

5. Car owner? $\square$ Yes $\square$ No

6. How often do you go to health club?

$\square$ Never $\square 1$ - 2 times a month $\square$ More than 2 times a month $\square 1$ - 3 times a week $\square$ More than 3 times a week

7. What times are most convenient for you?

$\square$ Weekend $\square$ After work/evening $\square$ Before work/ morning $\square$ Lunchtime $\square$ In the daytime

8. What are your purposes for attending a health club? (Multiple choices)

$\square$ Look good $\square$ To improve health $\square$ To improve self- esteem $\square$ Lose weight $\square$ Gain strength $\square$ Relax $\square$ Socialize

$\square$ Achieve goals

9. In health club, what kind of environment do you prefer?

$\square$ High energy environment $\square$ Relaxing environment $\square$ Family friendly

10. What is the most important factor in choosing a health club?

$\square$ Convenience $\square$ Price $\square$ Facilities $\square$ Previous experience $\square$ Service $\square$ Family members or friends' opinions

$\square$ Brand/status $\square$ others

11. Which way do you prefer to pay fees? $\square$ subscription $\square$ pay as you go

12. Which subscription do you think reasonable and affordable? (Per month)

$\square £ 10-£ 30 \square £ 31-£ 50 \square £ 51-£ 70 \square$ Above£70

13. Are you a member of a gym? $\square$ Yes $\square$ No

If Yes,

a) Which club:

$\square$ David Lloyd $\square$ Curves $\square$ Greens health \& fitness $\square$ Total fitness $\square$ The gym $\square$ Harbor health \& fitness club

$\square$ Village hotel \& fitness club $\square$ LA fitness $\square$ ARK health \& fitness $\square$ DW sports fitness centre $\square$ Lifestyle

$\square$ Small private gyms $\square$ others

b) To what extent do you satisfy with your current health club?

Facilities: Satisfied 12345 Unsatisfied

Staff/service: Satisfied 12345 Unsatisfied

Environment: Satisfied 12345 Unsatisfied

Price: Satisfied 12345 Unsatisfied

Location: Satisfied 12345 Unsatisfied

If No,

a) What are the main reasons that stop you joining a health club? (Multiple choices)

$\square$ Time pressure $\square$ Financial reasons $\square$ Prefer outdoor activities $\square$ No energy $\square$ Prefer exercise at home

$\square$ Exercising is boring $\square$ Non satisfied with services

b) Do you find health clubs intimidating? $\square$ Yes $\square$ No

If yes, what could be done to reduce any anxiety?

$\square$ Female only time $\square$ Separate gender exercise rooms $\square$ Personal trainers to help with equipment $\square$ More privacy

Other suggestions

\section{Appendix B-Primary Research Results}

\begin{tabular}{|c|c|c|c|c|c|c|c|c|c|c|c|}
\hline \multirow{3}{*}{$\begin{array}{l}\text { Question } \\
\text { number }\end{array}$} & \multirow{3}{*}{ Options } & \multirow{3}{*}{ Percentage } & $\begin{array}{c}\text { Your } \\
\text { location }\end{array}$ & $\begin{array}{l}\text { John } \\
\text { Lewis }\end{array}$ & $\begin{array}{l}\text { John Lewis, Streets } \\
\text { in city center }\end{array}$ & $\begin{array}{l}\text { Sports direct, Jjb, } \\
\text { Tesco, Liverpool one }\end{array}$ & $\begin{array}{l}\text { John } \\
\text { Lewis }\end{array}$ & Tesco & $\begin{array}{l}\text { John } \\
\text { Lewis }\end{array}$ & & \\
\hline & & & Volume & 15 & 15 & 16 & 15 & 15 & 15 & 91 & \\
\hline & & & & Quantity & Quantity & Quantity & Quantity & Quantity & Quantity & Sum & Percentage \\
\hline \multirow{2}{*}{ Q1 } & City center & $49.45 \%$ & & 8 & 4 & 8 & 9 & 8 & 8 & 45 & $49.45 \%$ \\
\hline & North liverpool & $14.29 \%$ & & 3 & 4 & 2 & 2 & 2 & & 13 & $14.29 \%$ \\
\hline
\end{tabular}




\section{Continued}

\begin{tabular}{|c|c|c|c|c|c|c|c|c|c|c|c|c|}
\hline & South liverpool & $12.09 \%$ & & & 3 & & 4 & 3 & & 1 & 11 & $12.09 \%$ \\
\hline & Knowsley & $2.20 \%$ & & & 1 & & 1 & & & & 2 & $2.20 \%$ \\
\hline & St.Helens & $0.00 \%$ & & & & & & & & & 0 & $0.00 \%$ \\
\hline & others & $17.58 \%$ & 4 & & 2 & & 1 & 1 & 3 & 5 & 16 & $17.58 \%$ \\
\hline & under 16 & $5.49 \%$ & 1 & & 2 & & & 1 & & 1 & 5 & $5.49 \%$ \\
\hline & $16-25$ & $56.04 \%$ & 9 & & 7 & & 6 & 9 & 12 & 8 & 51 & $56.04 \%$ \\
\hline & $26-35$ & $23.08 \%$ & 4 & & 3 & & 3 & 3 & 3 & 5 & 21 & $23.08 \%$ \\
\hline Q2 & $36-45$ & $6.59 \%$ & 1 & & 1 & & 3 & & & 1 & 6 & $6.59 \%$ \\
\hline & $46-55$ & $4.40 \%$ & & & 1 & & 1 & 2 & & & 4 & $4.40 \%$ \\
\hline & $56-65$ & $4.40 \%$ & & & 1 & & 3 & & & & 4 & $4.40 \%$ \\
\hline & above 66 & $0.00 \%$ & & & & & & & & & 0 & $0.00 \%$ \\
\hline & Male & $50.55 \%$ & 11 & & 7 & & 5 & 6 & 6 & 11 & 46 & $50.55 \%$ \\
\hline पर & Female & $49.45 \%$ & 4 & & 8 & & 11 & 9 & 9 & 4 & 45 & $49.45 \%$ \\
\hline O4 & Yes & $20.88 \%$ & 1 & & 2 & & 9 & 4 & 2 & 1 & 19 & $20.88 \%$ \\
\hline Q & No & $79.12 \%$ & 14 & & 13 & & 7 & 11 & 13 & 14 & 72 & $79.12 \%$ \\
\hline & Yes & $35.16 \%$ & 7 & & 2 & & 10 & 5 & 5 & 3 & 32 & $35.16 \%$ \\
\hline Qu & No & $64.84 \%$ & 8 & & 13 & & 6 & 10 & 10 & 12 & 59 & $64.84 \%$ \\
\hline & Never & $35.16 \%$ & 6 & & 6 & & & 4 & 7 & 9 & 32 & $35.16 \%$ \\
\hline & $\begin{array}{l}1 \text { - } 2 \text { times a } \\
\text { month }\end{array}$ & $20.88 \%$ & 4 & & 6 & & 6 & & 2 & 1 & 19 & $20.88 \%$ \\
\hline Q6 & $\begin{array}{l}\text { More than } 2 \\
\text { times a month }\end{array}$ & $28.57 \%$ & 1 & & 2 & & 10 & 7 & 3 & 3 & 26 & $28.57 \%$ \\
\hline & $\begin{array}{c}1 \text { - } 3 \text { times a } \\
\text { week }\end{array}$ & $13.19 \%$ & 3 & & & & & 4 & 3 & 2 & 12 & $13.19 \%$ \\
\hline & $\begin{array}{l}\text { More than } 3 \\
\text { times a week }\end{array}$ & $2.20 \%$ & 1 & & 1 & & & & & & 2 & $2.20 \%$ \\
\hline & Weekend & $38.46 \%$ & 4 & & 7 & & 10 & 5 & 2 & 7 & 35 & $38.46 \%$ \\
\hline & $\begin{array}{c}\text { After } \\
\text { work/evening }\end{array}$ & $47.25 \%$ & 10 & & 6 & & 4 & 5 & 13 & 5 & 43 & $47.25 \%$ \\
\hline Q7 & $\begin{array}{c}\text { Before } \\
\text { work/morning }\end{array}$ & $6.59 \%$ & 1 & & 2 & & 2 & 1 & & & 6 & $6.59 \%$ \\
\hline & Lunchtime & $0.00 \%$ & & & & & & & & & 0 & $0.00 \%$ \\
\hline & In the daytime & $7.69 \%$ & & & & & & 4 & & 3 & 7 & $7.69 \%$ \\
\hline Question & & Ations & 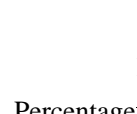 & $\begin{array}{l}\text { Your } \\
\text { location }\end{array}$ & $\begin{array}{l}\text { John } \\
\text { Lewis }\end{array}$ & $\begin{array}{l}\text { John Lewis, } \\
\text { Streets in } \\
\text { city center } \\
\end{array}$ & $\begin{array}{l}\text { Sports direct, } \\
\text { Jjb, Tesco, } \\
\text { Liverpool one }\end{array}$ & $\begin{array}{l}\text { John } \\
\text { Lewis }\end{array}$ & Tesco & $\begin{array}{l}\text { John } \\
\text { Lewis }\end{array}$ & & \\
\hline number & & & & Volume & 15 & 15 & 16 & 15 & 15 & 15 & 91 & \\
\hline & & & & & Quantity & Quantity & Quantity & Quantity & Quantity & Quantity & Sum $\mathrm{F}$ & Percentage \\
\hline & & Yes & $46.15 \%$ & & 6 & 5 & 7 & 10 & 8 & 6 & 42 & $46.15 \%$ \\
\hline & & No & $53.85 \%$ & & 9 & 10 & 9 & 5 & 7 & 9 & 49 & $53.85 \%$ \\
\hline Q13 & & David Lloyd & $9.52 \%$ & & & & 1 & & 3 & & 4 & $9.52 \%$ \\
\hline & IF Yes a) & Curves & $2.38 \%$ & & & & 1 & & & & 1 & $2.38 \%$ \\
\hline & Gre & ens Health \& Fitness & $7.14 \%$ & & 1 & & 1 & 1 & & & 3 & $7.14 \%$ \\
\hline
\end{tabular}




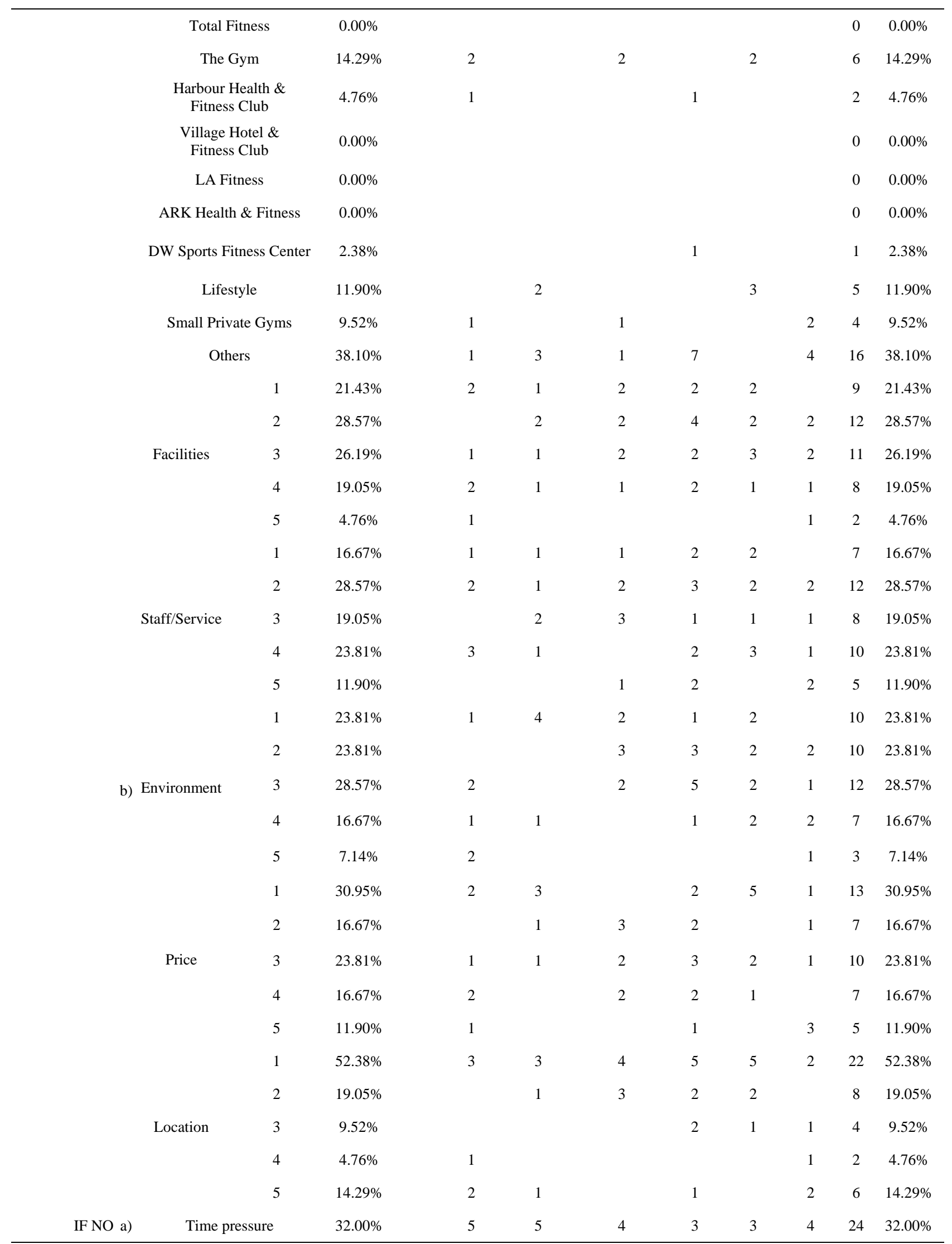




\section{Continued}

\begin{tabular}{|c|c|c|c|c|c|c|c|c|c|c|c|c|}
\hline & Financ & cial reasons & & $26.67 \%$ & 3 & 5 & 2 & 1 & 3 & 6 & 20 & $26.67 \%$ \\
\hline & Prefer out & tdoor activi & & $17.33 \%$ & 2 & 2 & 3 & 1 & 4 & 1 & 13 & $17.33 \%$ \\
\hline & & energy & & $5.33 \%$ & & 1 & & 1 & & 2 & 4 & $5.33 \%$ \\
\hline & Prefer exe & ercise at ho & & $8.00 \%$ & & 3 & & 1 & 1 & 1 & 6 & $8.00 \%$ \\
\hline & Exercis & se is boring & & $8.00 \%$ & 1 & 1 & & & & 4 & 6 & $8.00 \%$ \\
\hline & $\begin{array}{l}\text { Non } \\
\text { with }\end{array}$ & $\begin{array}{l}\text { satisfied } \\
\text { services }\end{array}$ & & $2.67 \%$ & & 1 & & & & 1 & 2 & $2.67 \%$ \\
\hline & & & & & & & & & & & 75 & \\
\hline & & No & & $59.18 \%$ & 5 & 5 & 7 & 3 & 3 & 6 & 29 & $59.18 \%$ \\
\hline & & Yes & & $40.82 \%$ & 4 & 5 & 2 & 2 & 4 & 3 & 20 & $40.82 \%$ \\
\hline & & male only ti & & $13.79 \%$ & & 4 & & & & & 4 & $13.79 \%$ \\
\hline & $\begin{aligned} & \text { Se } \\
& \text { ex }\end{aligned}$ & $\begin{array}{l}\text { eparate gen } \\
\text { xercise roor }\end{array}$ & & $20.69 \%$ & & 2 & & 1 & 2 & 1 & 6 & $20.69 \%$ \\
\hline & $\begin{aligned} \text { IF Yes } \begin{array}{r}\text { Pers } \\
\text { help }\end{array}\end{aligned}$ & $\begin{array}{l}\text { sonal traine } \\
\text { with equip }\end{array}$ & $\begin{array}{l}\text { rs to } \\
\text { ment }\end{array}$ & $24.14 \%$ & 2 & 1 & & & 3 & 1 & 7 & $24.14 \%$ \\
\hline & & More privac & & $37.93 \%$ & 2 & 4 & 1 & 1 & 2 & 1 & 11 & $37.93 \%$ \\
\hline & & ler suggesti & ons & $3.45 \%$ & & & 1 & & & & 1 & $3.45 \%$ \\
\hline & & & $\begin{array}{l}\text { Your } \\
\text { location }\end{array}$ & $\begin{array}{l}\text { John } \\
\text { Lewis }\end{array}$ & $\begin{array}{l}\text { John Lewis, Streets } \\
\text { in city center }\end{array}$ & & $\begin{array}{l}\text { Sports direct, Jjb, } \\
\text { esco, Liverpool one }\end{array}$ & $\begin{array}{l}\text { John } \\
\text { Lewis }\end{array}$ & Tesco & $\begin{array}{l}\text { John } \\
\text { Lewis }\end{array}$ & & \\
\hline $\begin{array}{l}\text { Question } \\
\text { number }\end{array}$ & Options & Percentage & Volume & 15 & 15 & & 16 & 15 & 15 & 15 & 91 & \\
\hline & & & & Quantity & Quantity & & Quantity & Quantity & Quantity & Quantity & Sum & Percentage \\
\hline & Look good & $14.38 \%$ & & 3 & 1 & & 2 & 5 & 4 & 6 & 21 & $14.38 \%$ \\
\hline & To improve health & $30.82 \%$ & & 10 & 6 & & 6 & 7 & 5 & 11 & 45 & $30.82 \%$ \\
\hline & $\begin{array}{l}\text { To improve } \\
\text { self-esteem }\end{array}$ & $8.22 \%$ & & 1 & 2 & & 4 & 1 & & 4 & 12 & $8.22 \%$ \\
\hline O8 & Lose weight & $23.29 \%$ & & 2 & 8 & & 6 & 7 & 10 & 1 & 34 & $23.29 \%$ \\
\hline & Gain Strength & $4.11 \%$ & & 1 & & & 1 & & & 4 & 6 & $4.11 \%$ \\
\hline & Relax & $11.64 \%$ & & 2 & 2 & & 3 & 4 & 4 & 2 & 17 & $11.64 \%$ \\
\hline & Socialize & $5.48 \%$ & & 2 & 2 & & 2 & & & 2 & 8 & $5.48 \%$ \\
\hline & Achieve goals & $2.05 \%$ & & & 2 & & & 1 & & & 3 & $2.05 \%$ \\
\hline & & & & & & & & & & & 146 & \\
\hline & $\begin{array}{l}\text { High energy } \\
\text { environment }\end{array}$ & $29.67 \%$ & & 7 & 5 & & 4 & 3 & & 8 & 27 & $29.67 \%$ \\
\hline Q9 & Relaxing environment & $62.64 \%$ & & 8 & 9 & & 10 & 9 & 15 & 6 & 57 & $62.64 \%$ \\
\hline & Family Friendly & $7.69 \%$ & & & 1 & & 2 & 3 & & 1 & 7 & $7.69 \%$ \\
\hline & Convenience & $27.47 \%$ & & 1 & 5 & & 6 & 2 & 8 & 3 & 25 & $27.47 \%$ \\
\hline & Price & $30.77 \%$ & & 7 & 4 & & 4 & 3 & 2 & 8 & 28 & $30.77 \%$ \\
\hline & Facilities & $20.88 \%$ & & 5 & 4 & & 3 & 2 & 3 & 2 & 19 & $20.88 \%$ \\
\hline Q10 & Previous experience & $2.20 \%$ & & & & & & 2 & & & 2 & $2.20 \%$ \\
\hline & Service & $10.99 \%$ & & 1 & 1 & & 1 & 3 & 2 & 2 & 10 & $10.99 \%$ \\
\hline & $\begin{array}{l}\text { Family members or } \\
\text { friends' opinions }\end{array}$ & $6.59 \%$ & & 1 & & & 2 & 3 & & & 6 & $6.59 \%$ \\
\hline
\end{tabular}




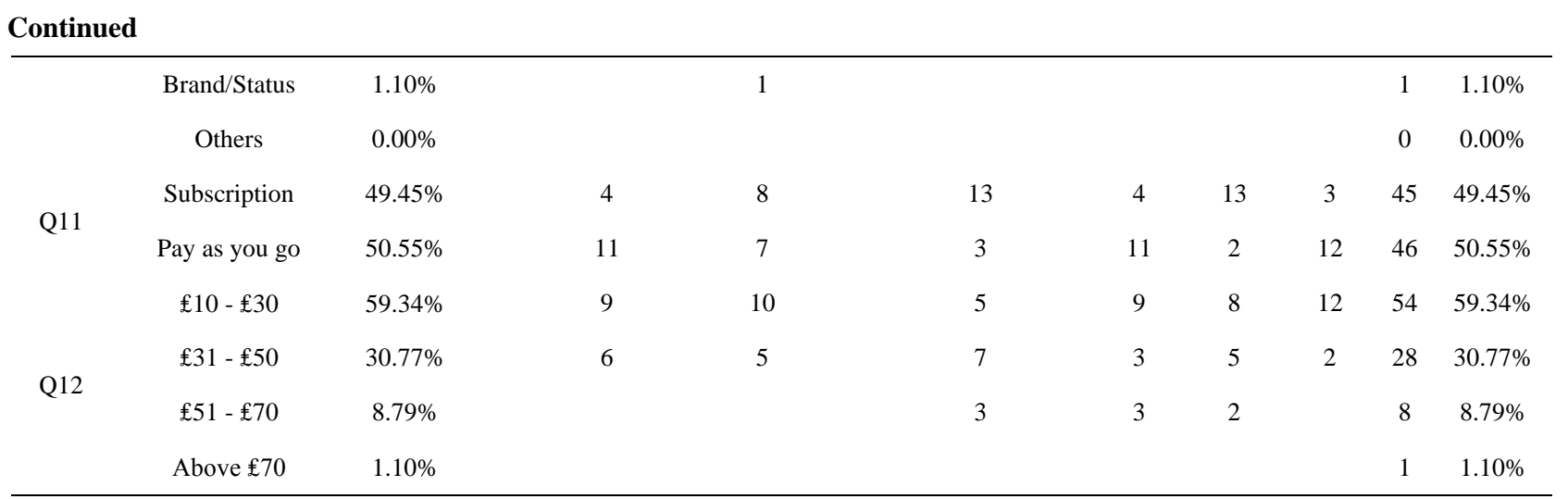

\section{Appendix C-Primary Research Analysis}

- Most respondents don’t own car (79.12\%), but half of them are member of gym, So own car is not unique factor influence their intention to be a member, it affected by multiple elements, price, convenience, facilities. see Q10

- More than half respondents are in their 16 - 25 ages (56.04\%).

- Q8, In general, their main purpose for attending a health club is to improve health, except that, more female choose lose weight, more male choose improve self-esteem and socialize.

- Q9 most women prefer relaxing environment, man like both high energy and relaxing environment

- Q10 the most important factor is: Price (30.77\%) second is convenience (27.47\%), third is facilities (20.88\%)

- Q11 the numbers of people prefer subscription nearly equal as pay as you go.
- Q12 it is obvious people will choose the cheapest one.

- Q13 the members of gym mostly are people in their $16-35$.

- Q14 ranks (except others): 1. The Gym 2. lifestyle 3. David Lloyd

IF YES

In general, people are satisfied with their health clubs current situation

But Staff/service does not get high evaluation.

There is difference between different clubs.

Lifestyle gets high evaluation.

IF NO

Main reasons stop joining health club is: 1 . Time pressure (32\%) 2. Financial reasons $(26.67 \%) 3$. prefer outdoor activities (17.33\%)

The people who feel health club is intimidating hope it could be more privacy (37.93\%), and think personal trainers (24.14\%) and separate gender rooms (20.69\%) are good idea. 